\title{
Correction to: From National to Cross-Border Support of Renewable Electricity in the European Union
}

\author{
Sebastian Busch and André Ortner
}

\section{Correction to:}

\section{Chapter 11 in: E. Gawel et al. (eds.), The European}

Dimension of Germany's Energy Transition, https://doi.org/10.1007/978-3-030-03374-3_11

The original version of Chapter 11 was inadvertently published with the incorrect city and country name appearing in the affiliation of the author Sebastian Busch. The affiliation 'Knowledge for the Energy Union Unit, European Commission, Joint Research Centre, Ispra, Italy' has been updated as 'Knowledge for the Energy Union Unit, European Commission, Joint Research Centre, Petten, The Netherlands.' Further, the original version of this chapter inadvertently did not contain the below disclaimer and now has been added as per author's request.

\section{Disclaimer}

The views expressed are purely those of the author and may not be regarded as stating an official position of the European Commission. 